"In the undulating region of Travancore, where the waterbearing strata heave and fall according to the locality concerned, bearing strata heave and of professional men who are generally I have come across a set of pro to sink wells in view to ascertain consulted by those who wish to sink wells in view to ascertain whether, at a given spot, a well may be sunk with the probability of finding water near where the springs will be men undertake to predict where the springs will be found near, and whe are generally verified with great accuand their prok some trouble to ascertain how these men racy. I took some trouble to ascertain how these men arushing aside the ceremonies and incantations they perform in view to deceive others and perhaps themselves they perform in view to detect the proximity of the subterranean springs by lying down on the bare ground in the dead silence of night, with the ear in contact with the ground, and trying to hear the sound of the flow of water in the strata beneath. By practice the ear is made very sensitive, and the degree of distinctness with which they hear the sound of flowing water enables them approximately to predict the depth of the springs. It is in this manner that appropriate spots are selected for sinking wells.

"Now, would any of the instruments you are experimenting with magnify the sound of the subterranean flow of water so as to greatly facilitate the process I have described? If so, it may be a considerable practical gain."

To this query I have hitherto been able to return no other answer than a negative one. Both the subjects are practical ones, and I only hope that there will be before long some light cast upon them.

Baroda, India, November 4

\section{Leaf-Sheaths and the Growth of Plants}

THE latest results of M. Bert's researches into the growth of plants (see Comptes Rendus, vol. 87, p. 695, November 4), have Jed me to publish an observation which $I$ made on the inner sheaths of young leaves this last spring. The spring before last I was struck with the crimson-lilse colour of these silky sheaths on many trees, whereas the young leaves they cover are of a tender green, and it naturally occurred to me that their purpose was not only to form a wrapper to the leaf, but also a coloured scrcen, which would allow the red rays of the spectrum to pass, and to a certain extent quench the blue rays. But I could not understand why the latter rays should be cut off, since they are bighly actinic, and the leaves themselves are green. Last spring 1 carefully noted the tints of the leaf-sheaths of different trees, with the following results :-

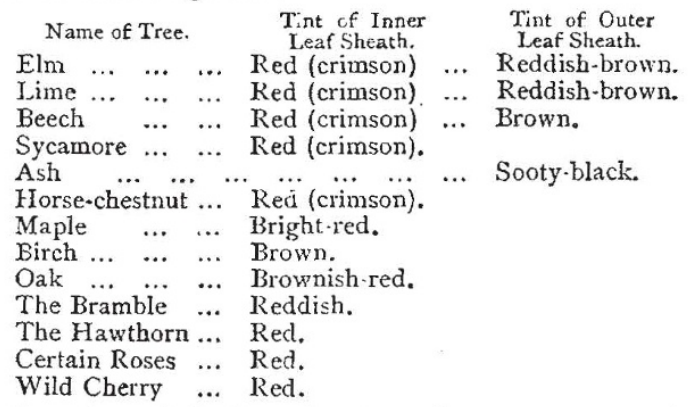

Sometimes the bark on the stem of young sycamore shoots and the top leaflets were tinged with a deep reddish-brown. The overlapping tips of young leaves in buds were frequently reddish and the majority of outer leaf-cases were a warm or reddishbrown. The shining buds of the horse-chestnut afforded a fine example of the phenomenon. The Jeaf-cases were of a strong red, like carmine, the exposed tip of each sheath leaflet being dyed a deeper red at the middle, shading off to the edges, where they overlapped. Under this protective curtain was a liyer of flossy fibre, like cotton, swathing the pale young leaves underneath.

The recent researches of $\mathrm{M}$. Bert throw light on this interesting subject. He finds that plants kept under green glass shades soon perish, because these intercept the red or less refrangible rays of the spectrum, and allow the blue or more refrangible rays to pass. Red glass, on the contrary, sustains life, although it becomes enfeebled by reason of the withdrawal of all the blue rays. M. Bert thinks that all the rays are necessary to the ful vigour of the plant, and in the proportion of the solar spectrum but it would appear from the care which nature has taken to redden the young leaf-cases, that for certain trees at least, the spring sunlight is richer in blue rays than she wishes, and there fore she has arranged that part of them shall be excluded, while all the red rays (or those which affect the maximum reduction of carbonic acid gas, and the building up of tissues) are allowed to pass into the leaf. I should add that this effect of colour is evidently superadded to the other functions of the sheath, as it usually appears as a more or less perfect colouring of the outer surface of the sheath only.

West Croydon JOHN MUNRO

\section{Hornets}

THE following fact, which I have been enabled to verify concerning a hornet, may be interesting to some of the readers of NATURE:-In a letter I received from my grandson, a very observing and accurate young naturalist, there was the following statement, dated October 13, r878, Tunbridge Wells:-

"Last week I caught a splendid large hornet on the hall window, and last Saturday I caught a smaller one on a small oak-tree in Hurst Wood (Tunbridge Wells). He was engaged in eating some sticky, whitish stuff which had come out of the tree in several places where it had been cut or bruised. This stuff seemed to attract all the insects in the neighbourhood, especially swarms of flies. There were two red admirals (butterflies), two hornets, four wasps, and hundreds of bluebottles and other small flies, busily engaged in eating this substance, which was bored with small round holes. On Sunday, as we came home from Speldhurst Church, we passed the same tree, and on it, to my great surprise, I canght half a hornet, which was very active, running about the tree, and seemed to be quite happy and comfortable. He had no abdomen at all, except a small piece of the upper skin, wbich hung on; his left wings were very much battered, and he had lost his left hind leg." This half hornet was brought home and examined, keeping actively alive until the evening, when it was destroyed for the sake of preservation. I had an opportunity of examining the half hornet alluded to very soon after, and the facts detailed in the letter I have quoted were ascertained to be quite correct. This hornet was a small specimen, and I found all the abdomen gone except a small portion of the upper part of the first joint, which still remained attached to the thorax. The left wings were much broken, and one bind leg gone. In this disabled state, how long the hornet might have lived is a point which I regret was not ascertained.

Raystead, Worthing

WM. WILSON SAUNDERS

\section{Equine Sagacity}

A pleasant story has just come to us from the Cape of Good Hope. In Graaf-Reinett, as in all the old Cutch towns in the colony, there is, in the centre of the place, a large market square, where the farmers, traders, and others, arriving with their produce at any hour of the day or night, may "out-span" the oxen or horses from their waggons, send the cattle out to the "commonage" to feed, while they bivonac at their waggons, as is the wont of African travellers to do, until the eight o'clock morning market auction.

An old horse belonging to one of these parties had wandered about in search of grass and water-vainly, no doubt, for it was during the severe drought from which the country is but now recovering. Coming to the great bare market-place, and finding a knot of mentalking there, he singled out one of them, and pulled him by the sleeve with his teeth. The man, thinking the horse might possibly bite, repulsed him, but as it was not very roughly done, he returned to the charge, with the same reception; but he was a persevering animal, and practically demonstrated the axiom that "perseverance gains the day," for upon his taking the chosen sleeve for the third time between his teeth, the owner awoke to the idea that a deed of kindness might be required of him; so, putting his hand upon the horse's neck, he said, "All right, old fellow; march on !" The horse at once led the way to a pump at the further side of the square. Some coloured servants were lounging about the spot. One of them, at the bidding of the white man, filled a bucket with water; three times was the bucket replenished and emptied before the "great thirst" was acsuaged, and then the grateful brute almost spole his thanks to his white friend by rubbing his 